www.jmscr.igmpublication.org

Impact Factor (SJIF): 6.379

Index Copernicus Value: 71.58

ISSN (e)-2347-176x ISSN (p) 2455-0450

crossref DOI: _https://dx.doi.org/10.18535/jmscr/v6i2.145

\title{
Prevalence \& Initiation Timing of Breast Feeding Practices with its key Determinants among Mothers of Rural Field Practice Area of a Medical Institute of Central India
}

\author{
Authors \\ Dr P. Adhikari ${ }^{1}$, Dr Ranjana Tiwari ${ }^{2}$, Dr Vikas Dwivedi ${ }^{3}$ \\ ${ }^{1}$ Asstt Professor, Community Medicine, S S Medical College, Rewa, M.P \\ 2Professor, Community Medicine, G R Medical College, Gwalior, M.P \\ ${ }^{3}$ Medical Officer, Distt Hospital Chindawara, M.P. \\ Corresponding Author \\ Dr Ranjana Tiwari \\ Professor, Community Medicine, G R Medical College, Gwalior, M.P India
}

\begin{abstract}
Introduction: Breast milk the "Cinderella substance of the decade" is nature's most precious gift to the newborn, and equivalent of which is yet to be innovated by our scientific community despite tremendous advances in science and technology. Breastfeeding is therefore a key aspect of self-reliance and primary health care.

Objectives: To assess the prevalence of breast feeding practices among mothers \& to correlate breast feeding initiation in relation with variables.

Methodology: The present study was a cross sectional (observational) community based study conducted in rural field practices area of medical college Gwalior from $1^{\text {st }}$ July 2010 to $30^{\text {th }}$ June 2011. Study subject were randomly selected 400 lactating mothers having infants aged 0-6 months.

Results: the prevalence of EBF, predominant breast feeding and partial breast feeding was found 27.0\%,38 $\%$ \& $31.25 \%$ respectively but $3.75 \%$ mothers did not initiated breast feeding within 1 hour after birth, the main causes behind all such low prevalence of EBF and late initiation of breast feeding was found illiteracy, and place of delivery etc.

Conclusions: In the present study prevalence of $E B F$ was found lower than the national reference data although it is well known that breast feeding is one of the most cost effective measure to prevent the malnutrition in infants so that there should be door step approach awareness campaign regarding breast feeding in relation to the various importances of early initiation of breast feeding and practice of exclusive breast feeding.

Keyword: $E B F$, prevalence, lactating mothers.
\end{abstract}

\section{Introduction}

Every child has the right to be adequately nourished.; the right to be loved, nurtured and fed by the mother is the most ancient of all human rights, recognized by all societies and cultures, breast feeding is one of the most finest and nobel aspect of this right. Breast feeding is an ideal food for neonate, a mother who gives the birth of baby 
also gives the breast feeding as the best gift to her baby ${ }^{1}$ Breast feeding is the feeding of an infant or young child with breast milk directly from female human breasts (i.e., via lactation) rather than from a baby bottle or other container ${ }^{2}$. Breast milk the "Cinderella substance of the decade" is nature's most precious gift to the newborn, and equivalent of which is yet to be innovated by our scientific community despite tremendous advances in science and technology. Breastfeeding is therefore a key aspect of self-reliance and primary health care $^{3}$.

As per the Joint WHO/UNICEF Meeting on Infant and Young Child Feeding WHO held in 1979 "Poor infant feeding practices and their consequences are one of the world's major problems and a serious obstacle to social and economic development. It is not only a problem of the developing world: it occurs in many parts of the developed world as well. Breastfeeding should be sustained well into or belong the second year with increasing amounts of complementary foods"4.

According NFHS - 3 in all over India only $46.4 \%$ of women exclusive breast fed their children and only $23.4 \%$ women initiates Breast feeding within 1 hour., but in case of M.P. state as per NFHS, only $21.6 \%$ women exclusive breast fed their children and only $14.9 \%$ women initiates Breast feeding within 1 hour. ${ }^{5}$ But as per recently published NFHS-4 survey findings these all data has been found improved as $52.1 \%$ Indian mothers exclusively breast feed their children and $42.8 \%$ mothers initiated breast feed within one hour of birth and in case of M.P. these figures remains as $54.2 \%$ and $31.6 \%$ respectively ${ }^{6}$, although it found as improvement in practices of breast feeding but it needs to be increased universally to reduce IMR .

Several studies have shown that exclusive breastfeeding for six months is nutritionally adequate and provides protection against many acute and chronic illnesses in children of the developing as well as the developed world. Breast feeding for 6 months as a potential to reduce under 5 mortality by $13 \%$ it is the most effective intervention to reduce neonatal and under 5 deaths, if every baby were exclusively breastfed from birth for 6 months, an estimated 1.5 million lives would be saved each year ${ }^{1,7}$.

\section{Objectives}

1. To assess the prevalence of breast feeding practices among mothers.

2. To correlate breast feeding initiation practices in relation with educational status and place of delivery..

\section{Methodology}

Background Information- The present study was conducted in Block Barai, Distt. Gwalior. The whole population (as per census 2011) of this Block was $1,81,025$, in which male population was 97,114 and female population was 83,911.The distance of the Block PHC Barai from G.R. Medical College is $22 \mathrm{~km}$.

Study Design: The present study was a cross sectional (observational) study

Study Area: The study areas were randomly selected 24 villages from whole Block Barai. From whole Block Barai all major five health facilities (CHC/PHCs) were selected and after this 24 villages were randomly selected from each $\mathrm{CHC} / \mathrm{PHCs}$ area

Study Duration: $1^{\text {st }}$ July 2010 to $30^{\text {th }}$ June 2011.

Study Subjects: Study subject were lactating mothers having infants aged 0-6 months.

Sampling Method: The overall method used was random sampling. For the selection of the villages the Multistage Random Sampling method was used in this method. Total 24 villages were selected randomly from the whole block Barai for purpose of study area for present study. 23 Mothers were selected randomly from each villages.

Sample size: The study population was 400 mothers of Block Barai having infants of age 0 to 6 months with no any feeding problems and were apparently healthy. 
Sample size calculation

Formula $\mathbf{N}=\mathbf{4 P Q} / \mathbf{L}^{2}$, Where Sample size $=\mathrm{N}$, Prevelance $=\mathrm{p},=22 \quad \%, \mathrm{Q}=(100-\mathrm{P}) \quad=78$ and Allowable error $=\mathrm{L}=20 \%$ of Prevalence Hence, $\mathrm{N}=4 \times 22 \times 78 / 19.36=354.4$ and drop out was kept $10 \%$ hence total sample size was kept 400 .

Study Tool: A predesigned \& pretested questionnaire (Close ended and Open ended) based, semi structured proforma was used to collect the information about all variables

Inclusion Criteria: Mothers who were healthy, were in lactating period, having baby of 0 to 6 six months of age in apparently healthy condition and with no any congenital feeding problems and mothers who were giving consent were included in the study.

Exclusion Criteria: Mothers Extremely ill, having Babies who were having feeding problem like cleft lip \& cleft plate and not willing to participate in this study were excluded.

Informed Consent: Verbal consent obtained from the subjects after explaining the purpose, nature and procedure of the study.

Data Collection: Study respondents were contacted for in-depth interviews of mother having 0-6 months age of baby with the help of female health worker by using a pretested, semi structured proforma which consists of various close and open ended kinds of questionnaires. Data Processing and Analyzing - It was done by using various required statistical methods like percentage and proportions, using graphs and tables by manually or by using suitable statistical software i.e.Epica-info2000. All necessary writing or computer errors were sorted out accordingly.

\section{Results}

In case of exclusive breast feeding practices out of total $27 \%$ mothers, max. mothers were literate $(23.5 \%)$ and only few of them were illiterate (3.5\%), same pattern of predominant breast feeding practice was found with the literate mothers but in case of partial breast feeding max. mothers were illiterate. $(22.0 \%)$ and only $9.25 \%$ mothers were literate but in case of no breast feeding started max. mothers were illiterate mothers $(2.50 \%)$. And only $1.25 \%$ mothers were literate. (Table No-1)

Table No. 1 Prevalance of Breast Feeding Practices in Relation to Educational Status of mothers

\begin{tabular}{|c|c|c|c|c|c|c|}
\hline S.No. & $\begin{array}{l}\text { Types of breast } \\
\text { feeding practices }\end{array}$ & $\begin{array}{c}\text { No of } \\
\text { mothers }\end{array}$ & $\begin{array}{c}\text { Percentages } \\
(\%)\end{array}$ & $\begin{array}{c}\text { Educational } \\
\text { status of } \\
\text { mothers. }\end{array}$ & $\begin{array}{c}\text { No. of } \\
\text { mothers }\end{array}$ & $\begin{array}{c}\text { Percentages } \\
(\%)\end{array}$ \\
\hline 1. & $\begin{array}{l}\text { Exclusive breast } \\
\text { feeding }\end{array}$ & 108 & 27.0 & $\begin{array}{c}\text { Literate } \\
\text { Illiterate }\end{array}$ & $\begin{array}{l}94 \\
14\end{array}$ & $\begin{array}{c}23.5 \\
3.5\end{array}$ \\
\hline 2. & $\begin{array}{c}\text { Predominant } \\
\text { breast feeding }\end{array}$ & 152 & 38.0 & $\begin{array}{l}\text { Literate } \\
\text { Illiterate }\end{array}$ & $\begin{array}{c}132 \\
20 \\
\end{array}$ & $\begin{array}{c}33.0 \\
5.0\end{array}$ \\
\hline 3. & $\begin{array}{l}\text { Partial breast } \\
\text { feeding }\end{array}$ & 125 & 31.25 & $\begin{array}{l}\text { Literate } \\
\text { Illiterate }\end{array}$ & $\begin{array}{l}37 \\
88\end{array}$ & $\begin{array}{l}9.25 \\
22.0\end{array}$ \\
\hline 4. & None & 15 & 3.75 & $\begin{array}{l}\text { Literate } \\
\text { Illiterate }\end{array}$ & $\begin{array}{l}05 \\
10 \\
\end{array}$ & $\begin{array}{l}1.25 \\
2.50 \\
\end{array}$ \\
\hline & Total & 400 & 100 & & 400 & 100 \\
\hline
\end{tabular}

Among of $19.5 \%$ mothers who have initiated breast feeding within half an hour max mothers were literate (19.0\% out of $19.5 \%)$ and remaining mothers were illiterate who have initiated breast feeding within half an hour. similarly the number of mothers who have initiated breast feeding within 1 hour also found among more literate mothers in comparison of illiterate mothers. $(17.25 \%$ vs6.5\%) but in case of breast feeding not yet started mothers max. were found as illiterate. $(2.5 \%$ out of $3.75 \%)$. only $1.25 \%$ mothers were literate who have not started breast feeding at the time of observation. (Table No 2) 
Table No. 2 Time of initiation of breast feeding in relation with educational status of mothers

\begin{tabular}{|l|c|c|c|c|c|c|}
\hline S.No. & $\begin{array}{c}\text { Time of initiation } \\
\text { of breast feeding }\end{array}$ & $\begin{array}{c}\text { No. of } \\
\text { mothers }\end{array}$ & $\begin{array}{c}\text { Percentages } \\
(\boldsymbol{\%})\end{array}$ & $\begin{array}{c}\text { Educational } \\
\text { status of mothers }\end{array}$ & $\begin{array}{c}\text { No. of } \\
\text { mothers }\end{array}$ & $\begin{array}{c}\text { Percentages } \\
(\boldsymbol{\%})\end{array}$ \\
\hline 1. & Within 1 /2 hrs & 78 & 19.5 & $\begin{array}{c}\text { Literate } \\
\text { Illiterate }\end{array}$ & 76 & 19.0 \\
& & & & Literate & 69 & 17.25 \\
\hline 2. & Within $1 \mathrm{hr}$ & 95 & 23.75 & Illiterate & 26 & 6.5 \\
\hline 3. & Within $2-4 \mathrm{hr}$ & 96 & 24 & Literate & 66 & 16.5 \\
& & & & Illiterate & 30 & 7.5 \\
\hline 4. & Within> 4 hr & 116 & 29 & Literate & 52 & 13.0 \\
& & & & Illiterate & 64 & 16.0 \\
\hline 5. & Not yet started & 15 & 3.75 & Literate & 5 & 1.25 \\
& & & & Illiterate & 10 & 2.5 \\
\hline
\end{tabular}

Among of mothers who were have initiated breast feeding within half an hour max. among of them were from delivered at govt. apex hospital $(5.0 \%)$ and from PHC $(5.25 \%)$ and min. among of them were form home delivery $(0.75 \%)$ in case of breast feeding started in more than four hour max. among of them were from home delivery and govt. apex delivery (9\% and $8.25 \%)$ it may be $\mathrm{d} / \mathrm{t}$ that interventional mode of delivery was done in case of more than four hour initiation of breast feeding at govt. apex hospital. mothers who were still not started breast feeding were also found max. in case of home delivery. $(2.5 \%$ out of $3.75 \%$ ) (Table No 3)

Table No. 3 Time of initiation of breast feeding in relation with palace of delivery

\begin{tabular}{|c|c|c|c|c|c|c|}
\hline S.No. & $\begin{array}{c}\text { Time of initiation of } \\
\text { breast feeding }\end{array}$ & $\begin{array}{c}\text { No. of } \\
\text { Mothers }\end{array}$ & $\begin{array}{c}\text { Percentages } \\
(\%) \\
\end{array}$ & $\begin{array}{c}\text { Palace of } \\
\text { delivery }\end{array}$ & $\begin{array}{c}\text { No. of } \\
\text { Mothers } \\
\end{array}$ & $\begin{array}{c}\text { Percentages } \\
(\%) \\
\end{array}$ \\
\hline 1. & Within $1 / 2 \mathrm{hrs}$ & 78 & 19.5 & $\begin{array}{c}\text { GAH } \\
\text { DH } \\
\text { CHC } \\
\text { PHC } \\
\text { PH } \\
\text { HOME }\end{array}$ & $\begin{array}{l}20 \\
10 \\
20 \\
21 \\
04 \\
03\end{array}$ & $\begin{array}{c}5.0 \\
2.5 \\
5.0 \\
5.25 \\
1.0 \\
0.75\end{array}$ \\
\hline 2. & Within $1 \mathrm{hr}$ & 95 & 23.75 & $\begin{array}{c}\text { GAH } \\
\text { DH } \\
\text { CHC } \\
\text { PHC } \\
\text { PH } \\
\text { HOME }\end{array}$ & $\begin{array}{l}05 \\
03 \\
30 \\
44 \\
00 \\
13\end{array}$ & $\begin{array}{c}1.25 \\
0.75 \\
7.5 \\
11.0 \\
00.0 \\
3.25\end{array}$ \\
\hline 3. & Within $2-4 \mathrm{hr}$ & 96 & 24 & $\begin{array}{c}\text { GAH } \\
\text { DH } \\
\text { CHC } \\
\text { PHC } \\
\text { PH } \\
\text { HOME }\end{array}$ & $\begin{array}{l}10 \\
03 \\
24 \\
30 \\
02 \\
27\end{array}$ & $\begin{array}{c}2.5 \\
0.75 \\
8.0 \\
7.5 \\
0.5 \\
6.75\end{array}$ \\
\hline 4. & Within $>4 \mathrm{hr}$ & 116 & 29 & $\begin{array}{c}\text { GAH } \\
\text { DH } \\
\text { CHC } \\
\text { PHC } \\
\text { PH } \\
\text { HOME }\end{array}$ & $\begin{array}{l}33 \\
06 \\
19 \\
13 \\
09 \\
36 \\
\end{array}$ & $\begin{array}{c}8.25 \\
1.5 \\
4.75 \\
3.25 \\
2.25 \\
9.0 \\
\end{array}$ \\
\hline 5. & $\begin{array}{l}\text { Breast feeding not yet } \\
\text { started }\end{array}$ & 15 & 3.75 & $\begin{array}{c}\text { GAH } \\
\text { DH } \\
\text { CHC } \\
\text { PHC } \\
\text { PH } \\
\text { HOME }\end{array}$ & $\begin{array}{l}00 \\
00 \\
02 \\
03 \\
00 \\
10 \\
\end{array}$ & $\begin{array}{c}00.0 \\
00.0 \\
0.5 \\
0.75 \\
00.0 \\
2.5\end{array}$ \\
\hline & Total & 400 & 100 & Total & 400 & 100 \\
\hline
\end{tabular}

Abbreviations used - GAH= Govt Apex Hospital, DH= Distt Hospital, PHC=Primary Health Centre, CHC=Community Health Centre etc. 


\section{Discussion}

In the present study the prevalence of exclusive breast feeding was found $27.0 \%$ but in the other hand the prevalence of predominant breast feeding was found $38.0 \%$ and prevalence of partial breast feeding was $31.25 \%$. remaining $3.75 \%$ mothers were not have initiated breast feeding at the time of study because at that time among of these mothers some of mothers have recently delivered and some of them were admitted to the hospital due to some sort of problems i.e. problems related to mothers and related to the babies which were found in the observations. All babies of these mothers were of less than 7 days of age. In case of exclusive breast feeding practices max. mothers were literate $(23.5 \%)$ and only few of them were illiterate $(3.5 \%)$. same pattern of predominant breast feeding practice was found with the literate mothers but in case of partial breast feeding max. mothers were illiterate. $(22.0 \%)$ and only $9.25 \%$ mothers were literate but in case of no breast feeding started max. mothers were illiterate mothers $(2.50 \%)$ and only $1.25 \%$ mothers were literate.

Similar pattern of initiation of breast feeding was found by K Madhu et al (2009) ${ }^{8}$ that Most of the mothers initiated breastfeeding $(97 \%)$ and the other $3 \%$ were not able to initiate due to separation from mother $(2 \%)$ or due to advice from the mother-in-law (1\%). Similarly According NFHS $-3^{5}$ in all over India only $46.4 \%$ of women exclusive breast fed their children but in case of M.P. state as per NFHS-3, only $21.6 \%$ women exclusive breast fed their children but as per recently published NFHS-4 survey findings these all data has been found as $52.1 \%$ Indian mothers exclusively breast feed their children and $42.8 \%$ mothers initiated breast feed within one hour of birth and in case of M.P. these figures remains as $54.2 \%$ and $31.6 \%$ respectively ${ }^{6}$. As per $\mathrm{WHO}^{9}$ Globally less than $40 \%$ of infants under six months of age are exclusively breast fed.T M Samuel et al $(2011)^{10}$ found that only $14.2 \%$ remained as exclusively breastfed by month 6 in Banglore but complementary feeding
(CF) was introduced as early as 1 month among $44 \%$ of the infants in the same study group. Reason for the early introduction of CF was primarily a crying infant In fact this prevalence of exclusive breast feeding is more than the NFHS-3 reference data but it should be more than this specially in M.P. state where the malnutrition is quite higher than the other states. The various factors which affected the rate of exclusive breast feeding in the present study are low level of educational status cause max number of participants who were illiterate practiced partial breast feeding and max. number of participants who were literate practiced exclusive breast feeding. place of delivery was also an important factor for this low level of exclusive breast feeding. Shipra Kunwar et al (2010) ${ }^{11}$ found in OPD of Era's medical college locknow that only $75.8 \%$ practiced exclusive breast feeding with the mean duration of exclusive breast feeding (EBF) being 3.5 months with only $41 \%$ practicing EBF for six months. Better education was the only factor significantly affecting $\operatorname{EBF}(p<0.004)$ Maheswari Ekambaram et al (2010) ${ }^{12}$ in south india found that $47.3 \%$ was the EBF rate. $\mathrm{K}$ Madhu et al (2009) ${ }^{8}$ found at PHCarea of Karnataka that Only $40 \%$ of the mothers did the exclusive breastfeeding until 6 months and started weaning after 6 months. Oommen A et al(2009) ${ }^{13}$ found that The exclusive breastfeeding rates were $38 \%, 30 \%, 24 \%, 20 \%, 16 \%$ and $1 \%$ at discharge, $1.5,2.5,3.5,4.5$ and 6 months, respectively in the urban and; $57 \%, 16 \%, 9 \%, 6 \%, 5 \%$ and $0 \%$ at discharge, $1.5,2.5,3.5,4.5$ and 6 months, respectively in rural setting attertiary care hospital of Delhi and rural First Referral Unit in Haryana in 2009. Apurba Sinhababu et al(2008) ${ }^{14}$ conducted a cross sectional study during June-July 2008 to assess the infant- and young child-feeding (IYCF) practices in Bankura district, West Bengal, India and found that $57.1 \%$ was the prevelance of Exclusive Breast Feeding. Similarly M. Sai Sunil Kishore ${ }^{\mathrm{a}}$ et al (2009) ${ }^{15}$ found that $30 \%$ and $10 \%$ exclusively breastfed their infants till 4 and 6 months of age, 
respectively at Haryana in 2009. Negi KS et $\mathrm{al}(2004)^{16}$ found that in Dehradun. 56.3\% mothers reported to have fed colostrums, $74.1 \%$ mothers put their children on full breast-feeding while only $26.0 \%$ with partial breast-feeding. Literacy and socio- economic status had a significant association with the duration of breast- feeding $(p<0.001)$. Ranjana Tiwari, et al $(2008)^{17}$ found that The actual rate of Exclusive Breast Feeding (EBF) (up to the age of 6 months) is dismally low in urban slums of India. The reasons and determinants of this are debatable. Only $7.8 \%$ actually practiced EBFin urban slums of Gwalior. It was found that EBF was more common amongst the women who had frequent contacts with health facilities due to any reason or during ANC or immunization visit. Mandal PK et al $(2007)^{18}$ in W.B also found that exclusive breast feeding was persistently lower compared to national values. It also showed a steady decline with age and dropped to $10 \%$ at 6 months of age. $15 \%$ were predominantly breast fed and $75 \%$ were partially breast fed at that age. Suneth B Agampod et $\mathrm{al}(2007)^{19}$ found in Sri Lanka that the rates of exclusive breastfeeding at 4 and 6 months were $61.6 \%(135 / 219)$ and $15.5 \% \quad(24 / 155)$ respectively. the Muslim ethnicity $(\mathrm{p}=0.004)$, lower levels of parental education $(p<0.001)$ and being an unemployed mother $(p=0.021)$ were important associations of early cessation of exclusive breastfeeding.

\section{Conclusions}

In the present study prevalence of EBF was found lower than the national reference data although it is well known that breast feeding is one of the most cost effective measure to prevent the malnutrition in infants so that there should be a regular target group( antenatal mothers \& mothers having baby less than 6 month of age) oriented door step approach awareness campaign regarding breast feeding in relation to the various importances of early initiation of breast feeding and practice of exclusive breast feeding.

\section{References}

1. Ghai O.P, essientials of Pediatrics,CBS Publishers ,7th edition page 122-125.

2. http://www.who.int/topics/breastfeeding/e $\mathrm{n} /$

3. Subbiah, Nanthini, A study to assess the knowledge, attitude, practice and problems of postnatal mothers regarding breastfeeding, Nursing Journal of India / aug 2003

4. World Health Organization (WHO /UNICEF): Meeting on infant and young child feeding. Statement and Recommendations. World Health Organization: Geneva, 1979.

5. www.nfhsindia.org/nfhs3.shtm

6. rchiips.org/NFHS/factsheet_NFHS4.shtml

7. Park K ,Text Book of PSM/community medicine, $21^{\text {st }}$ edition, Bhanot publication, page no 488 .

8. K Madhu, Sriram Chowdary, and Ramesh Masthi, Breast feeding practices and new born care in rural areas:A descriptive Crossectional StudyIndian J Community Med.v.34(3); Jul 2009 Issue : 3 | Page : 243-246

9. www.who.int/features/factfiles/breastfeedi ng/en/index.html.

10. T M Samuel, T Thomas, S Bhat and A V Kurpad, Are infants born in baby-friendly hospitals being exclusively breastfed until 6 months of age? European Journal of Clinical Nutrition ejcn.2011.179 ,(19 October 2011)

11. Shipra Kunwar, Mohammad. M. A. Faridi, Shivani Singh1, Fatima Zahra, Zeashan Alizaidi, Pattern and determinants of breast feeding and contraceptive practices among mothers within six months postpartum, Bio Science Trends. 2010; 4(4):186-189.

12. Maheswari Ekambaram, Vishnu Bhat B, Mohamed Asif Padiyath Ahamed, Knowledge, attitiude and practice of 
breastfeeding among postnatal Mothers, Curr Pediatr Res 2010; 14 (2): 119-124.

13. Oommen A, Vatsa M, Paul VK, Aggarwal RIndian ,Breastfeeding practices of urban and rural mothers, Indian Pediatr. 2009 Oct;46(10):891-4. Epub 2009 Apr

14. Apurba Sinhababu, Dipta K. Mukhopadhyay, Tanmay K. Panja, Asit B. Saren, Nirmal K. Mandal, and Akhil B. Biswas, J Health Popul Nutr. 2010 June; 28(3): 294-299.

15. M. Sai Sunil Kishore,, Praveen Kumar, Arun K. Aggarwal 2009 Breastfeeding Knowledge and Practices amongst Mothers in a Rural Population of North India: A Community-based Study, (Journal of Tropical Pediatrics Volume55, Issue3 Pp. 183-188.

16. Negi KS,Kandpal SD, Breast feeding practices in a rural area of District Dehradun, Uttaranchal,Indian journal of preventive and social medicine. Vol 35,no. 3 and 4, 2004

17. Ranjana Tiwari, P. C. Mahajan Chandrakant Lahariya,The Determinants of Exclusive Breast Feeding in Urban Slums: A Community Based StudyJournal of Tropical Pediatrics 2008 Volume55, Issue1 Pp. 49-54

18. Mandal PK; Sardar JC; Chatterjee C; Lahiri SK; Ghosh P, A study of breast feeding practices among infants in a rural area of West Bengal., Indian Journal of Preventive and Social Medicine. 2007 JanJun;38(1-2):28-31

19. Suneth B Agampodi, Thilini C Agampodi and Udage Kankanamge D Piyaseeli, Breastfeeding practices in a public health field practice area in Sri Lanka: a survival analysis, International Breastfeeding Journal 2007, 2:13. 